\title{
Inactivation of Shiga Toxin-Producing Escherichia coli in Refrigerated and Frozen Meatballs Using High Pressure Processing
}

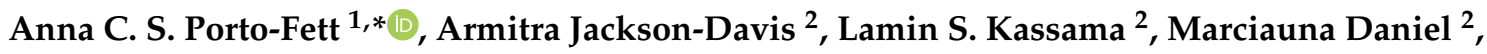 \\ Michelle Oliver ${ }^{2}$, YangJin Jung ${ }^{1}$ and John B. Luchansky ${ }^{1}$ \\ 1 United States Department of Agriculture, Agricultural Research Service, Eastern Regional Research Center, \\ 600 East Mermaid Lane, Wyndmoor, PA 19038, USA; yangjin.jung@usda.gov (Y.J.); \\ john.luchansky@usda.gov (J.B.L.) \\ 2 Department of Food and Animal Sciences, Alabama Agricultural and Mechanical University, \\ 4900 Meridian St. N, Normal, AL 35762, USA; armitra.davis@aamu.edu (A.J.-D.); \\ lamin.kassama@aamu.edu (L.S.K.); marciauna0420@yahoo.com (M.D.); \\ moliver9@bulldogs.aamu.edu (M.O.) \\ * Correspondence: anna.portofett@usda.gov; Tel.: +1-215-836-3762
}

Received: 3 February 2020; Accepted: 26 February 2020; Published: 3 March 2020

\begin{abstract}
High pressure processing (HPP) was evaluated to inactivate Shiga toxin-producing Escherichia coli (STEC) in raw meatballs. Ground meat (>90\% lean) was inoculated (ca. $7.0 \log$ CFU/g) with a rifampicin-resistant cocktail of eight STEC strains (O26:H11, O45:H2, O103:H2, O104:H4, O111:H-, O121:H19, O145:NM, and O157:H7). Inoculated ground beef, ground veal, or a mixture of ground beef, pork, and veal were separately mixed with liquid whole eggs and seasonings, shaped by hand into meatballs ( $40 \mathrm{~g}$ each), and stored at -20 or at $4{ }^{\circ} \mathrm{C}$ for at least $18 \mathrm{~h}$. Samples were then exposed to 400 or $600 \mathrm{MPa}$ for 0 to $18 \mathrm{~min}$. There were no differences $(p>0.05)$ in pathogen reduction related to the species of meat used or for meatballs that were refrigerated ( 0.9 to $2.9 \log$ $\mathrm{CFU} / \mathrm{g}$ ) compared to otherwise similar meatballs that were stored frozen (1.0 to $3.0 \mathrm{log} \mathrm{CFU} / \mathrm{g}$ ) prior to HPP treatment. However, less time was needed to achieve $\mathrm{a} \geq 2.0 \log \mathrm{CFU} / \mathrm{g}$ reduction at $600 \mathrm{MPa}$ ( 1 to $3 \mathrm{~min}$ ) compared to $400 \mathrm{MPa}$ (at least $9 \mathrm{~min}$ ). This work provides new and practically useful information on the use of HPP to inactivate STEC in raw meatballs.
\end{abstract}

Keywords: Shiga toxin-producing Escherichia coli (STEC); high pressure processing; ground meat; meatballs; veal; beef

\section{Introduction}

Consumption of under-processed and improperly handled or stored food products contaminated with Escherichia coli O157:H7 or non-O157:H7 Shiga toxin-producing cells of E. coli (STEC) are responsible for ca. 265,000 illnesses annually (ca. 5300 laboratory confirmed), as well as ca. 3600 hospitalizations and ca. 30 deaths each year [1]. Cells of serotype O157:H7 STEC have been recognized as a human pathogen since the early 1980s; however, cells of a handful of non-O157 STEC serogroups-namely O26, O45, O103, O111, O121, and O145 (also known as "the big six")- -have only more recently been implicated in foodborne illness [2] and are the etiologic agent for 70 to $83 \%$ of confirmed non-O157:H7 illness attributed to STEC in the U.S. [1]. As such, the Food Safety and Inspection Service (FSIS) of the U.S. Department of Agriculture (USDA) issued regulations stipulating that cells of serotype O157:H7 and cells of the big six non-O157 STEC serogroups are considered adulterants in non-intact beef and veal products, including ground beef and related products containing comminuted beef such as raw meatballs [3]. For these reasons, much effort has focused on developing and validating interventions to 
lower the occurrence and levels of cells of the seven regulated STEC serovars in food, and particularly in beef.

STEC illnesses are associated with undercooked or improperly handled not-ready-to-eat (NRTE) and non-intact beef products, as well as with other food commodities such as leafy greens [4]. Regarding physical interventions other than heat for reducing the risk of foodborne illness due to STEC in raw beef, high-pressure processing (HPP; 100 to $1000 \mathrm{MPa}$ for typically $<5 \mathrm{~min}$ ) is used commercially to inactivate microorganisms (reductions of up to five to six log) directly in/on foods without significant degradation of the food components and while preserving the sensory and nutritional qualities of treated foods [5]. As one example, Cutter et al. [6] inoculated irradiated ground beef patties (80:20 or 93:7 (lean:fat)) with $6.0 \log$ CFU/g of a cocktail of serogroup O26, O45, O103, O111, O121, O145, and O157:H7 cells of STEC and stored these patties at $4{ }^{\circ} \mathrm{C}$ prior to HPP treatment. After four $400 \mathrm{MPa}$ cycles of $1 \mathrm{~min}$ each at $17^{\circ} \mathrm{C}$, reductions of ca. three to four log were achieved [6]. As another example, Morales et al. [7] demonstrated that HPP reduced E. coli O157:H7 levels in ground beef by 0.82 and $4.39 \log$ CFU/g after 1 and 20 min exposures at $400 \mathrm{MPa}$, respectively; however, significant changes in color and texture were observed after $10 \mathrm{~min}$ of HPP treatment. Nonetheless, HPP is gaining favor and increasing use for enhancing safety and maintaining the wholesomeness of raw and ready-to-eat (RTE) red meat and poultry products [5].

Over the past 20 years, numerous recalls and several illnesses have been linked to improperly cooked ground beef and, to a much lesser extent, ground veal [8-11]. There has also been a recent outbreak and two recalls linked to meatballs [12-14]. The associated outbreak from one of these recalls was responsible for six hospitalizations, 18 illnesses, and one death caused by cells of a serogroup O26 STEC strain [13,14], whereas cells of a serogroup O157:H7 STEC strain were recovered from meatballs associated with the second abovementioned recall [12]. The reasons for these recalls of meatballs ranged from "extraneous material", "undetermined substances/allergens", and "without the benefit of federal inspection" to the presence of a pathogen such as Listeria monocytogenes, Salmonella, or STEC [12,15-17]. As such, if meatballs harbored STEC, albeit it at low frequency and at low levels, and if such meatballs were not properly cooked, handled, and stored, then such products could cause human illness. Although studies were published on the effect of HPP on inactivation of serotype O157:H7 strains of E. coli in ground meats [18,19], far less has been published on HPP inactivation of the big six non-O157 STEC serogroups in raw red meat and poultry products. Data are especially lacking for application of HPP to enhance the safety and quality of multi-species and multi-ingredient raw meats containing beef such as meatballs. Therefore, we evaluated the effect of different pressure levels and treatment times for HPP on inactivation of STEC in raw meatballs prepared with veal, beef, or a veal-beef-pork mixture.

\section{Materials and Methods}

\subsection{Preparation of Bacterial Strains}

The following eight rifampin-resistant (100 $\mu \mathrm{g} / \mathrm{mL}$; Sigma Chemical Company, St. Louis, MO, USA) strains of Shiga toxin-producing Escherichia coli (STEC-8) used to inoculate raw meat were prepared and maintained as described by Porto-Fett et al. [20]: (i) H30 (serotype O26:H11), (ii) JBI-95 (serotype O111:H-), (iii) CDC 96-3285 (serotype O45:H2), (iv) CDC 90-3128 (serotype O103:H2), (v) ATCC BAA-2326 (serotype O104:H4), (vi) CDC 97-3068 (serotype O121:H19), (vii) 83-75 (serotype O145:NM), and (viii) USDA-FSIS 011-82 (serotype O157:H7).

\subsection{Preparation and Inoculation of Meatballs}

Meatballs were prepared and inoculated as previously described [20]. Briefly, freshly processed and finely ground veal (veal; ca. 97:3\% (lean:fat)); finely ground beef (beef; ca. 90:10\% (lean:fat)); or finely ground beef, veal, and pork (meat mix containing ca. 1/3 of each species of meat; ca. 90:10\% (lean:fat)) were separately inoculated with the rifampicin-resistant STEC-8 cocktail ( $1 \mathrm{~mL}$ of inoculum 
to $100 \mathrm{~g}$ of ground meat) to achieve an initial inoculum of ca. $7.0 \log \mathrm{CFU} / \mathrm{g}$. The inoculated ground veal, ground beef, or ground meat mix (ca. $4.5 \mathrm{~kg}$ each) were separately combined with pasteurized liquid whole eggs (900 mL; EggBeaters ${ }^{\circledR}$; ConAgra Foods Inc., Omaha, NE, USA) and with flavored bread crumbs ( $850 \mathrm{~g}$; Cento ${ }^{\circledR}$; Cento Fine Foods Inc., Thorofare, NJ, USA) using a commercial mixer (Univex SRM12; Univex, Salem, NH, USA). Portions (40 g each) of the inoculated batter were shaped into balls by hand, placed individually into nylon-polyethylene bags (Koch Supplies, Kansas City, $\mathrm{MO}, \mathrm{USA}$ ) and vacuum-sealed to $950 \mathrm{mBar}$. Each bag was then placed into a second vacuum-sealed nylon-polyethylene bag and stored either at $-20^{\circ} \mathrm{C}$ (i.e., frozen) or at $4{ }^{\circ} \mathrm{C}$ (i.e., refrigerated) for 16 to $18 \mathrm{~h}$, before being subjected to pressurization as described below [21].

\subsection{High Pressure Processing Treatments}

Meatballs inoculated with the STEC-8 cocktail were subjected to $400 \mathrm{MPa}(58,015 \mathrm{psi})$ for $0,3,6,9$, or $12 \mathrm{~min}$ (fresh meatballs) or $0,9,12,15$, or $18 \mathrm{~min}$ (frozen meatballs) or $600 \mathrm{MPa}(87,023 \mathrm{psi}$ ) for $0,0.5,1,1.5$, or 3 min (fresh meatballs) or $0,1.5,3,6$, or 9 min (frozen meatballs) in a $2 \mathrm{~L}$ capacity HPP unit (Model $2 \mathrm{~L}$; Avure Technologies, Kent, WA, USA) essentially as described [21]. The pressure release times were instantaneous. The average initial temperature of the water in the pressure vessel was $19.2^{\circ} \mathrm{C}\left( \pm 2.2^{\circ} \mathrm{C}\right)$ and the temperature range attained after pressurizing to 400 or $600 \mathrm{MPa}$ was 22.4 to $27.6^{\circ} \mathrm{C}$ or 27.6 to $32.4^{\circ} \mathrm{C}$, respectively. After pressurization, meatball samples were removed from the HPP chamber and immediately placed on ice until microbiological analyses were conducted (within $\leq 30 \mathrm{~min}$ ).

\subsection{Microbiological Analyses}

After HPP treatment, cells of STEC were recovered from pressure-treated meatballs by aseptically transferring each sample into a filter bag (Type XX-C003; Microbiology International, Frederick, MD, USA) containing $60 \mathrm{~mL}$ of sterile $0.1 \%$ peptone water (Difco, Becton, Dickinson Co., Sparks, MD, USA) and macerating for $2 \mathrm{~min}$ at $230 \mathrm{rpm}$ in a stomacher (Stomacher 400; Seward, Cincinnati, OH, USA). Appropriate serial dilutions of the filtrate were prepared using sterile $0.1 \%$ peptone water before $0.1 \mathrm{~mL}$ aliquots were surface plated in duplicate onto sorbitol-MacConkey (SMAC; Difco) agar plates plus rifampicin $(100 \mu \mathrm{g} / \mathrm{mL})$. Plates were incubated for $24 \mathrm{~h}$ at $37^{\circ} \mathrm{C}$ before surviving cells typical for STEC were enumerated. When testing negative for the pathogen by direct plating $(\leq 0.40 \log \mathrm{CFU} / \mathrm{g})$, samples were enriched as described previously [22].

\subsection{Statistical Analyses}

The SAS system (Version 9.3; SAS Institute, Cary, NC, USA) was used to determine statistically significant differences among pressure times (i.e., 0 to $18 \mathrm{~min}$ ), pressure levels (i.e., 400 and $600 \mathrm{MPa}$ ), state of meat (i.e., refrigerated and frozen), and type of meat (i.e., veal, beef, or multi-species mix). At each of the two pressure levels tested, means and standard deviations were calculated from individual sets of data for each of the three separate trials using triplicate samples at each time interval. Analysis of variance (ANOVA) was used to determine the effects and interactions of the factors on the log reduction values. Differences in lethality observed for each time, pressure level, type of meat, state of meat, and/or combinations thereof were tested for significance at $p<0.05$ using the Sidak test. The D-values represent the absolute value of the inverse of the linear inactivation rate of the surviving cell fraction.

\section{Results}

In general, regardless of the type of meat used in the formulation (i.e., veal only, beef only, or a mix of veal, beef, and pork), the state of the meat (i.e., refrigerated vs. frozen) just prior to treatment via $\mathrm{HPP}$, or the level of pressure applied (i.e., $400 \mathrm{vs.} 600 \mathrm{MPa}$ ), longer treatment times produced a greater reduction in the levels of STEC-8. More specifically, when meatballs were pressurized at $400 \mathrm{MPa}$, there was no significant $(p>0.05)$ difference in the inactivation of STEC-8 between the state of meat or between the types of meat/formulations used to prepare refrigerated and frozen meatballs. However, the variables of time and time $\times$ state of the meat had a significant effect $(p<0.05)$ on lethality of STEC 
when meatballs were pressurized at $400 \mathrm{MPa}$ for up to $18 \mathrm{~min}$. Likewise, with the exception of the type of meat $(p>0.05)$ used to prepare the meatballs, we observed a significant $(p<0.05)$ difference between the state of meat, pressurization times, or the effect of time $\times$ state of the meat on the inactivation of STEC-8 when meatballs were subjected to $600 \mathrm{MPa}$.

For refrigerated meatballs pressurized at $400 \mathrm{MPa}$, statistical differences $(p<0.05)$ for inactivation of STEC-8 were observed within 3 min when compared with otherwise similar meatballs pressurized for 6, 9, or $12 \mathrm{~min}$, but not $(p>0.05)$ between meatballs that were pressurized for 6 and 9 min or that were pressurized for 9 and $12 \mathrm{~min}$. Likewise, statistical differences $(p<0.05)$ in thermal inactivation of STEC-8 were observed for frozen meatballs that were treated for $18 \mathrm{~min}$ at $400 \mathrm{MPa}$ compared with otherwise similar meatballs pressurized for 3 or $9 \mathrm{~min}$, but not for $15 \mathrm{~min}$. For refrigerated meatballs pressurized at $600 \mathrm{MPa}$, inactivation of STEC- 8 was similar $(p>0.05)$ in meatballs treated for $0.5 \mathrm{~min}$ when compared to $1 \mathrm{~min}$, but significantly $(p<0.05)$ less when compared to the inactivation observed in meatballs treated for 1.5 or $3 \mathrm{~min}$. For frozen meatballs, statistical differences $(p<0.05)$ in thermal inactivation of STEC-8 were observed among all pressurization times tested using $600 \mathrm{MPa}$. The $\mathrm{pH}$ and the water activity $\left(\mathrm{a}_{\mathrm{w}}\right)$ of the untreated meatballs ranged from 5.19 to 5.92 and 0.980 to 0.984 , respectively (data not shown).

Regardless of the type of meat, when refrigerated meatballs were subjected to $400 \mathrm{MPa}$ for 3 to $12 \mathrm{~min}$, pathogen numbers decreased by ca. 0.9 to $1.9 \mathrm{log}$ CFU/g (Figure 1), whereas when subjected to $600 \mathrm{MPa}$ for 0.5 to $3 \mathrm{~min}$, reductions of ca. 1.4 to $2.9 \mathrm{log} \mathrm{CFU} / \mathrm{g}$ were achieved (Figure 2). Likewise, when frozen meatballs were pressurized at $400 \mathrm{MPa}$ for 9 to $18 \mathrm{~min}$, pathogen numbers decreased by 1.4 to $3.0 \log \mathrm{CFU} / \mathrm{g}$ (Figure 1), whereas when subjected to $600 \mathrm{MPa}$ for 1.5 to $9 \mathrm{~min}$, reductions of 0.9 to $2.8 \log$ CFU/g were observed (Figure 2).

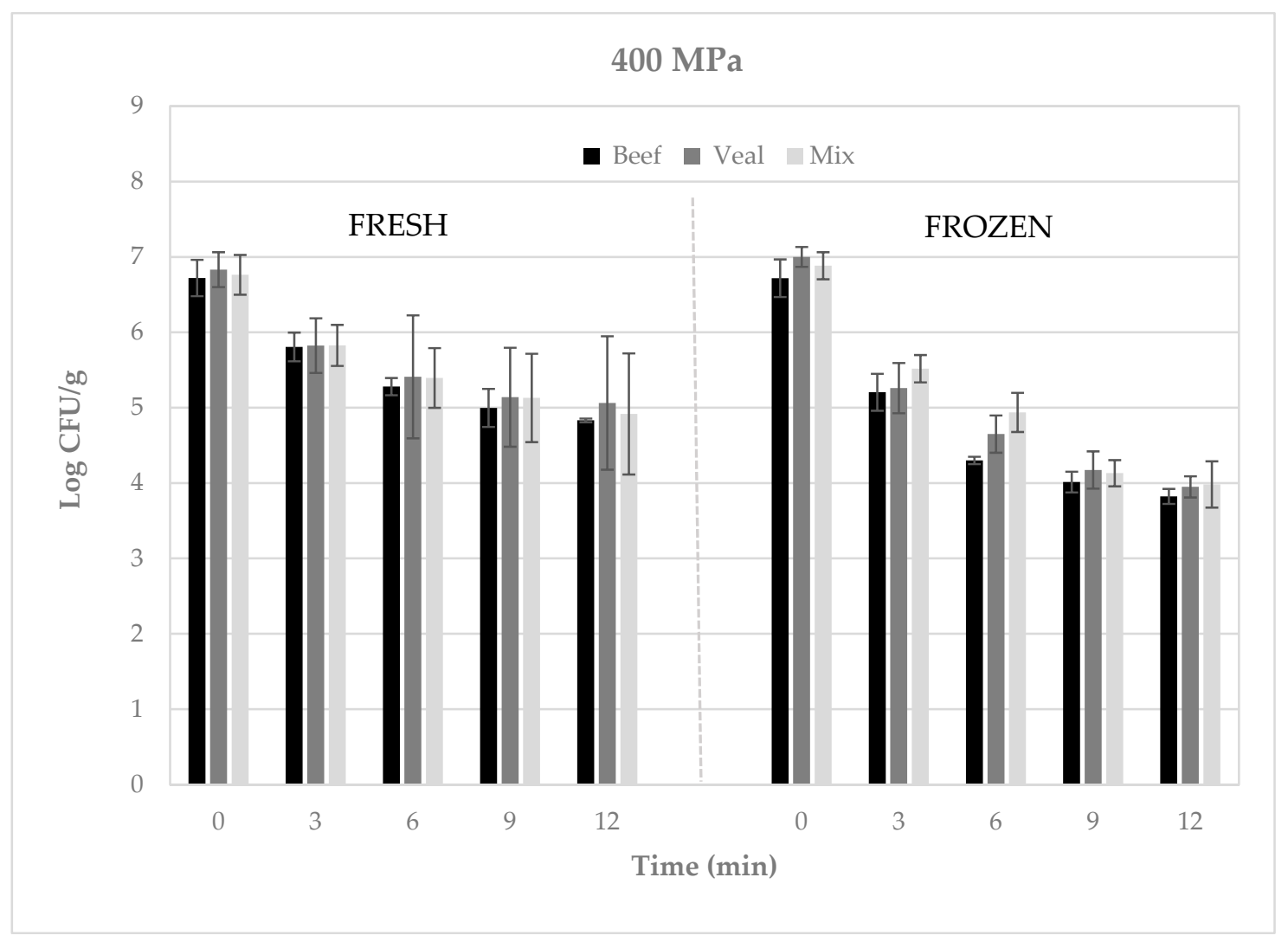

Figure 1. Recovery of Shiga toxin-producing Escherichia coli (log CFU/g) from refrigerated or frozen raw meatballs following pressure treatment at $400 \mathrm{MPa}$. Error bars represent the standard deviation of the mean $(\mathrm{N}=3, n=3)$. 


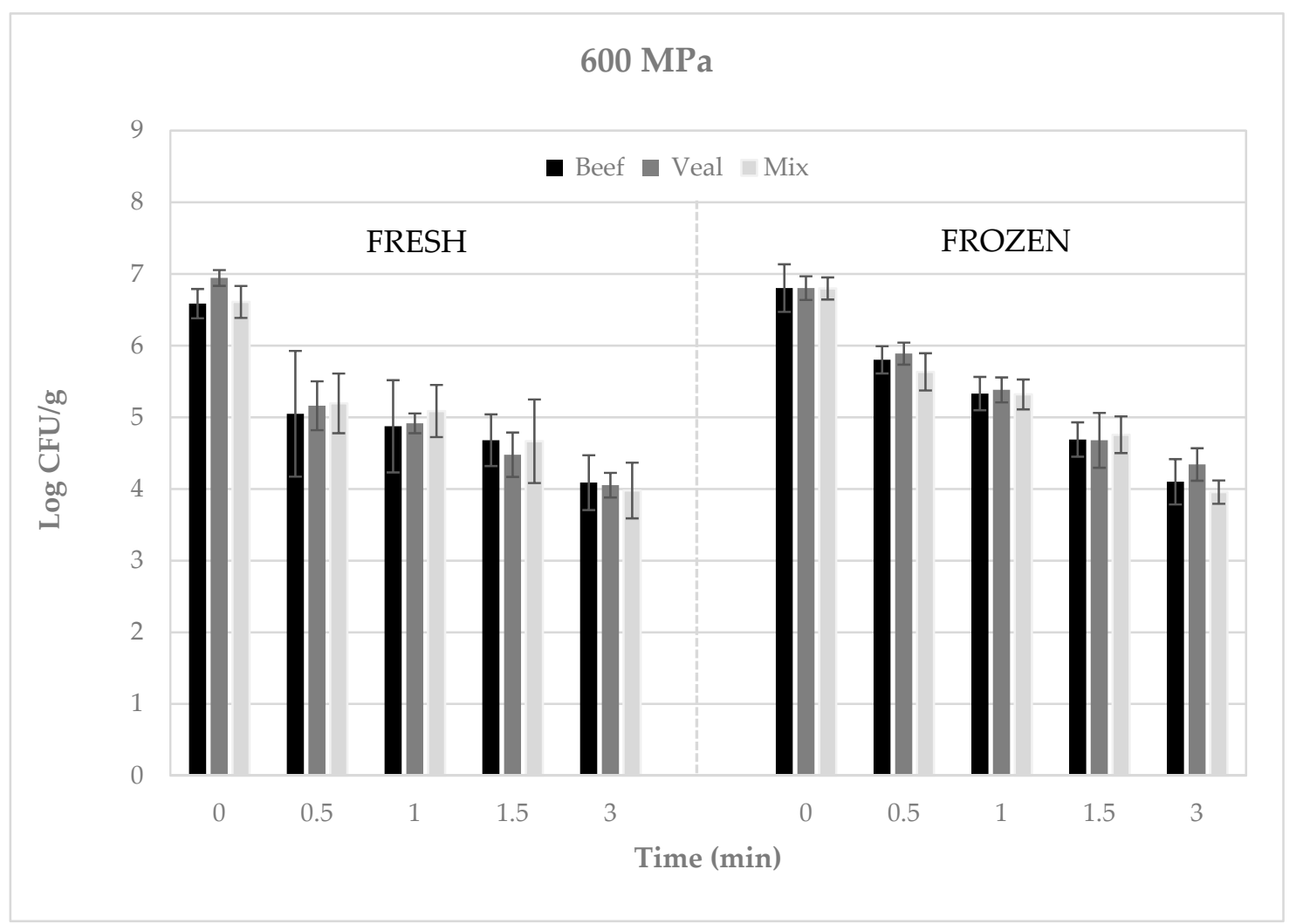

Figure 2. Recovery of Shiga toxin-producing Escherichia coli (log CFU/g) from refrigerated or frozen raw meatballs following pressure treatment at $600 \mathrm{MPa}$. Error bars represent the standard deviation of the mean $(\mathrm{N}=3, n=3)$.

The average D-values (Table 1) of STEC in refrigerated meatballs made with veal, beef, or the multi-species mix that were treated at 400 or $600 \mathrm{MPa}$ ranged from 6.54 to 7.10 or 1.24 to $1.45 \mathrm{~min}$, respectively. For frozen veal, beef, or the multi-specie meatballs pressurized at 400 and $600 \mathrm{MPa}$, the average D-values ranged from 5.69 to 5.90 and 3.56 to $3.80 \mathrm{~min}$, respectively. Our results also established that a 5-log reduction was achieved by pressurizing refrigerated or frozen meatballs at $400 \mathrm{MPa}$ for 32.7 to 35.5 and 28.45 to $29.45 \mathrm{~min}$, respectively, whereas a $5 \log$ reduction was achieved by pressure treating refrigerated or frozen meatballs at $600 \mathrm{MPa}$ for 6.20 to 7.25 or 17.80 to $19.3 \mathrm{~min}$, respectively (data not shown).

Table 1. D-values (min) for Shiga toxin-producing Escherichia coli in refrigerated and frozen meatballs pressure treated at 400 or $600 \mathrm{MPa}(\mathrm{N}=3$ trials, $n=3$ samples per trial).

\begin{tabular}{ccccc}
\hline \multirow{2}{*}{ State of Meat } & \multirow{2}{*}{ Pressure (MPa) } & \multicolumn{3}{c}{ Type of Meat } \\
\cline { 3 - 5 } & & Veal & Beef & Mixture $^{\mathbf{1}}$ \\
\hline \multirow{2}{*}{ Refrigerated } & 400 & 7.10 & 6.54 & 6.84 \\
\multirow{2}{*}{ Frozen } & 600 & 1.14 & 1.45 & 1.32 \\
& 400 & 5.69 & 5.89 & 5.90 \\
& 600 & 3.86 & 3.60 & 3.56 \\
\hline
\end{tabular}

${ }^{1}$ Mixture of ground beef, pork, and veal.

\section{Discussion}

Several recalls and illnesses have been linked to ground/non-intact beef and veal. There have also been reports on the recovery of STEC from ground/non-intact beef and veal, with the prevalence being somewhat higher for cells of the big six STEC than serotype O157:H7 STEC on veal than on 
beef [23]. In addition to a relatively low prevalence, for the infrequent occasions when STEC are recovered from raw beef products, pathogen levels are typically $<1.0 \log$ [24]. For these reasons, several investigators have elaborated cooking times and temperatures to appreciably reduce the levels of STEC in ground/non-intact beef and veal [25-27], including for thermal inactivation of STEC in meatballs [20]. Regarding the latter, reductions of 0.7 to $\geq 6.0 \log$ were achieved in 5.5 to $9.0 \mathrm{~min}$ when deep frying or oven cooking refrigerated meatballs, whereas 7.5 to $20 \mathrm{~min}$ were needed to achieve equivalent reductions for otherwise similar, but frozen, meatballs [20]. Note that meatballs may be purchased/stored as "frozen fully cooked", "frozen partially cooked", and/or "frozen raw". The growth temperature for STEC in foods can range from 7 to $46^{\circ} \mathrm{C}$, but strains of some STEC can survive at refrigeration and freezing temperatures for relatively long periods [28]. Thus, if meatballs are contaminated with STEC, the pathogen may survive during extended frozen storage. It is also quite common for consumers (22\%; 44 of 119 volunteer respondents) [29] and non-chain-style restaurants (26\%; 66 of 256) [30] to cook raw beef starting from a frozen state. To further lower the risk of STEC-related illness from consumption of under-processed and/or raw meatballs, we evaluated HPP to lower pathogen presence and load. As a clean label intervention, HPP provides producers and processors with an effective non-thermal option to ensure safety, enhance quality, and extend the shelf life of red meat and poultry products.

To the best of our knowledge, there is no research published on the effect of HPP to inactivate STEC in (multi-species) meatballs. Our results, however, are in general agreement with previous studies on HPP inactivation of STEC in ground beef and ground beef patties. For example, Jiang et al. [19] observed a ca. 2.3- to 4.3-log CFU/g reduction of non-O157:H7 and O157:H7 STEC cells in ground beef (80:20\% and 90:10\% (lean:fat)) samples that were pressurized at $400 \mathrm{MPa}$ during four consecutive cycles (60 s per cycle) at $17^{\circ} \mathrm{C}$. In another study, Hsu et al. [18] reported that reductions of 3.5 to $6.9 \mathrm{log}$ CFU/g were achieved for non-O157:H7 and O157:H7 STEC when ground beef (83:17\% (lean:fat)) was subjected to $450 \mathrm{MPa}$ for 5 or $15 \mathrm{~min}$. Black et al. [31] reported that HPP delivered a 3.0-log reduction in STEC O157:H7 in ground beef pressurized at $400 \mathrm{MPa}$ for $10 \mathrm{~min}$ at $20^{\circ} \mathrm{C}$. Similarly, Morales et al. [7] quantified reductions of ca. $2.5 \mathrm{log}$ CFU/g of STEC O157:H7 when ground beef was pressurized at $400 \mathrm{MPa}$ in a single cycle for $20 \mathrm{~min}$ at $12{ }^{\circ} \mathrm{C}$.

Cells of the seven serogroup-specific STEC regulated by USDA FSIS may be present in ground/non-intact beef and veal. Analysis of raw ground beef components (RGBC) samples, including veal, collected in federal plants in 2018 by USDA FSIS revealed that serotype O157:H7 cells were recovered at a frequency of $0.16 \%$ (6 of 3707 samples) from ground beef and at $0.0 \%$ ( 0 of 48 samples) for ground veal [32]. For non-O157 STEC, the pathogen was recovered at a frequency of $0.22 \%$ ( 8 of 3613 samples) for ground beef and at $6.67 \%$ (3 of 45 samples) for ground veal [32]. Thus, it is essential to validate interventions to deliver $\mathrm{a} \geq 5.0 \mathrm{log}$ reduction in STEC levels prior to human consumption to decrease the risk of illness associated with undercooked ground/non-intact raw meats such as meatballs.

Although HPP is an effective technology to inactivate foodborne pathogens in meats [33], at times pressurization can adversely affect the quality of the product, and particularly the quality of raw meats. The composition and texture of the raw meat immediately prior to pressurization can also influence the rate of temperature change and the overall transfer of heat, which, in turn, can appreciably impact the tolerance of STEC to heat or pressure and the quality of the product. For example, Gola et al. [34] reported a $\geq 5.0 \log$ reduction of a cocktail of eight strains of $E$. coli O157:H7 in raw ground beef treated at $700 \mathrm{MPa}$ for $5 \mathrm{~min}$; however, according to these authors, this combination of pressure and time had an unintended negative impact on the color and texture of the product. By empirical observation, pressurization either at 400 or $600 \mathrm{MPa}$ did not have any significant detrimental effects on either the quality or sensory attributes of the product in the present study. The global food market for HPP is currently estimated at ca. USD \$14 billion, and it is anticipated to reach ca. USD \$27 billion in 2023 and then rise to ca. USD $\$ 50$ billion by 2027 [35]. The projected growth of HPP is fueled, to a large extent, by an ever-increasing demand from consumers for clean label, high convenience, low preservative, and minimally processed foods [36]. Our data substantiate that HPP is an effective alternative to 
heat for inactivating STEC in raw meatballs and it does not result in appreciable untoward effects on product quality. Subjecting inoculated meatballs to pressures of 400 or $600 \mathrm{MPa}$ for up to $18 \mathrm{~min}$ was sufficient to deliver reductions of 0.9 to $3.0 \mathrm{log}$ CFU/g in STEC levels. This is significant as STEC levels typically would be low in raw ground beef and ground veal, and as additional lethality will be achieved by subsequent cooking. Lowering the recovery rate and pathogen levels in (raw) meatballs by HPP will presumably also lower the public health risk from STEC.

Author Contributions: The authors have participated in the following: conceptualization, A.C.S.P.-F. and J.B.L.; methodology, A.C.S.P.-F. and J.B.L.; validation, A.C.S.P.-F., J.B.L., M.D., and M.O.; formal analysis, A.C.S.P.-F., J.B.L., M.D., M.O., A.J.-D., L.S.K., and Y.J.; investigation, A.C.S.P.-F. and J.B.L.; resources, A.C.S.P.-F. and J.B.L.; data curation, A.C.S.P.-F. and Y.J.; writing-original draft preparation, A.C.S.P.-F. and J.B.L.; writing-review and editing, A.C.S.P.-F., J.B.L., Y.J., A.J.-D., and L.S.K.; supervision, A.C.S.P.-F. and J.B.L.; project administration, A.C.S.P.-F. and J.B.L.; funding acquisition, A.C.S.P.-F. and J.B.L. All authors have read and agreed to the published version of the manuscript.

Funding: This research was funded by Agriculture and Food Research Initiative, grant no. 2012-68003-30155 from the USDA National Institute of Food and Agriculture.

Acknowledgments: We extend our most sincere appreciation to Manuela Osoria, Bradley A. Shoyer, Laura Stahler, and Laura E. Shane (USDA, Agricultural Research Service, Eastern Regional Research Center; Wyndmoor, PA, uSA) for their contributions on this project. Mention of trade names or commercial products in this publication is to provide specific information and does not imply recommendation or endorsement by the U.S. Department of Agriculture (USDA). USDA is an equal opportunity provider and employer.

Conflicts of Interest: The authors declare no conflict of interest. The funders had no role in the design of the study; in the collection, analyses, or interpretation of data; in the writing of the manuscript, or in the decision to publish the results.

\section{References}

1. Scallan, E.; Hoekstra, R.M.; Angulo, F.J.; Tauxe, R.V.; Widdowson, M.A.; Roy, S.L.; Jones, J.L.; Griffin, P.M. Foodborne illness acquired in the United States-Major pathogens. Emerg. Infect. Dis. 2011, 17, 7-15. [CrossRef] [PubMed]

2. Mathusa, E.C.; Chen, Y.; Enache, E.; Hontz, L. Non-O157 Shiga toxin-producing Escherichia coli in foods. J. Food Prot. 2010, 73, 1721-1736. [CrossRef] [PubMed]

3. United States Department of Agriculture, Food Safety and Inspection Service. USDA Targeting Six Additional Strains of E. coli in Raw Beef Trim Starting Monday. 2012. Available online: https:/www.usda.gov/media/ press-releases/2012/05/31/usda-targeting-six-additional-strains-ecoli-raw-beef-trim-starting (accessed on 17 January 2020).

4. Gould, H.; Walsh, K.; Vieira, A.; Herman, K.; Williams, I.; Hall, A.; Cole, D. Surveillance for foodborne disease outbreaks. United States, 1998-2008. MMWR Morb. Mortal Wkly Rep. 2013, 62, 1-34.

5. Simonin, H.; Duranton, F.; de Lamballerie, M. New insights into the high-pressure processing of meat and meat products. Compr. Rev. Food Sci. Food Saf. 2012, 11, 285-306. [CrossRef]

6. Cutter, C.; Depasquale, D.; Hayes, J.; Seniviranthne, R.; Raines, C. Meat Science Review: HPP, Ground Beef and the ‘Big 6' STEC. 2012. Available online: https://www.provisioneronline.com/articles/98113-meatscience-review-hpp-ground-beef-and-the-big-6-stec (accessed on 17 January 2020).

7. Morales, P.; Calzada, J.; Avila, M.; Nunez, M. Inactivation of Escherichia coli O157:H7 in ground beef by single-cycle and multiple-cycle high-pressure treatments. J. Food Prot. 2008, 71, 811-815. [CrossRef] [PubMed]

8. United States Department of Agriculture, Food Safety and Inspection Service. Brown Packing Recalls Veal Products due to Possible E. coli Contamination. 2015. Available online: http://www.fsis.usda.gov/wps/portal/ fsis/topics/recalls-and-public-health-alerts/recall-case-archive/archive/2015/recall-104-2015-release (accessed on 19 December 2019).

9. United States Department of Agriculture, Food Safety and Inspection Service. Marcho Farms, Inc. Recalls Veal, Beef and Pork Products due to Possible non-O157 Shiga Toxin-Producing E. coli (STEC) Adulteration. 2017. Available online: https://www.fsis.usda.gov/wps/portal/fsis/topics/recalls-and-public-health-alerts/ recall-case-archive/archive/2017/recall-044-2017-release (accessed on 12 December 2019). 
10. United States Department of Agriculture, Food Safety and Inspection Service. Cargill Meat Solutions Recalls Ground Beef Products due to Possible E. coli O26 Contamination. 2018. Available online: https:/www.fsis.usda.gov/wps/portal/fsis/topics/recalls-and-public-health-alerts/recall-case-archive/ archive/2018/recall-081-2018-release (accessed on 17 December 2019).

11. United States Department of Agriculture, Food Safety and Inspection Service. Recalls and Public Health Alerts. 2019. Available online: https://www.fsis.usda.gov/wps/portal/fsis/topics/recalls-and-public-healthalerts/current-recalls-and-alerts (accessed on 19 December 2019).

12. United States Department of Agriculture, Food Safety and Inspection Service. Majestic Meat Company Recalls Ground Beef Products due to Possible E. coli O157:H7 Contamination. 2018. Available online: https://www.fsis.usda.gov/wps/portal/fsis/topics/recalls-and-public-health-alerts/recall-case-archive/ archive/2018/recall-113-2018-release (accessed on 17 December 2019).

13. Centers for Disease Control and Prevention. Outbreak of E. coli Infections Linked to Ground Beef. 2018. Available online: https://www.cdc.gov/ecoli/2018/o26-09-18/index.html (accessed on 19 December 2019).

14. Hanbury, M. Publix Is Recalling Ground Beef Products Because of Possible E. coli Contamination. 2018. Available online: https://www.businessinsider.com/publix-ground-beef-recall-possible-e-coli-2018-8 (accessed on 19 December 2019).

15. United States Department of Agriculture, Food Safety and Inspection Service. King's Command Foods, LLC. Recalls Beef Products due to Possible Foreign Matter Contamination. 2017. Available online: https://www.fsis.usda.gov/wps/portal/fsis/topics/recalls-and-public-health-alerts/recall-case-archive/ archive/2017/recall-023-2017-release (accessed on 18 December 2019).

16. United States Department of Agriculture, Food Safety and Inspection Service. Rich Products Corporation Recalls Beef Products due to Possible Listeria Contamination. 2018. Available online: https://www.fsis.usda.gov/wps/portal/fsis/topics/recalls-and-public-health-alerts/recall-case-archive/ archive/2018/recall-006-2018-release (accessed on 17 December 2019).

17. United States Department of Agriculture, Food Safety and Inspection Service. Stino Da Napoli Recalls Various Meat Products Produced without Benefit of Inspection. 2019. Available online: https://www.fsis.usda.gov/wps/portal/fsis/topics/recalls-and-public-health-alerts/recall-case-archive/ archive/2019/recall-006-2019-release (accessed on 18 December 2019).

18. Hsu, H.; Sheen, S.; Sites, J.; Cassidy, J.; Scullen, B.; Sommers, C. Effect of high-pressure processing on the survival of Shiga toxin-producing Escherichia coli (Big Six vs. O157:H7) in ground beef. Food Microbiol. 2015, 48, 1-7. [CrossRef] [PubMed]

19. Jiang, Y.; Scheinberg, J.A.; Senevirathne, R.; Cutter, C.N. The efficacy of short and repeated high-pressure processing treatments on the reduction of non-O157:H7 Shiga-toxin producing Escherichia coli in ground beef patties. Meat Sci. 2015, 102, 22-26. [CrossRef] [PubMed]

20. Porto-Fett, A.C.S.; Oliver, M.; Daniel, M.; Shoyer, B.; Stahler, L.; Shane, L.; Kassama, L.S.; Jackson-Davis, A.; Luchansky, J.B. The effect of deep frying or conventional oven cooking on inactivation of Shiga toxin-producing cells of Escherichia coli (STEC) in meatballs. J. Food Prot. 2016, 79, 723-731. [CrossRef] [PubMed]

21. Porto-Fett, A.C.S.; Call, J.E.; Shoyer, B.A.; Hill, D.E.; Pshebniski, C.; Cocoma, G.J.; Luchansky, J.B. Evaluation of fermentation, drying, and/or high pressure processing on viability of Listeria monocytogenes, Escherichia coli O157:H7, Salmonella spp., and Trichinella spiralis in raw pork and Genoa salami. Int. J. Food Microbiol. 2010, 140, 61-75. [CrossRef] [PubMed]

22. Luchansky, J.B.; Porto-Fett, A.C.S.; Shoyer, B.A.; Phillips, J.; Eblen, D.; Evans, P.; Bauer, N. Thermal inactivation of a single strain each of serotype O26:H11, O45:H2, O104:H4, O111:H-, O121:H19, O145:NM, and O157:H7 cells of Shiga toxin-producing Escherichia coli in wafers of ground beef. J. Food Prot. 2013, 76, 1434-1437. [CrossRef] [PubMed]

23. United States Department of Agriculture, Food Safety and Inspection Service. Testing of Raw Ground Beef Component (RGBC) Samples, Including Veal, for E. coli O157:H7 and Non-O157 Shiga Toxin-Producing E. coli (STEC): Year-to-Date Totals Source and Serotype. 2013. Available online: http://www.fsis.usda.gov/wps/portal/fsis/topics/data-collection-and-reports/microbiology/ec/rgbc0157h7-and-stec-results-ytd/rgbc-stec-results-beef-veal/rgbc-stec-results-bv (accessed on 17 December 2019). 
24. Warren, W. Characterization of E. coli O157:H7 Subprimal Beef Cuts Prior to Mechanical Tenderization. National Cattlemens' Beef Association Research Project Summary. 2002. Available online: https://www.beefresearch.org/CMDocs/BeefResearch/Safety_Project_Summaries/FY02_Characterization_of_ E_coli_O157H7_on_Subprimal_Beef.pdf (accessed on 17 January 2020).

25. Adler, J.M.; Geornaras, I.; Belk, K.E.; Smith, G.C.; Sofos, J.N. Thermal inactivation of Escherichia coli O157:H7 inoculated at different depths of non-intact blade tenderized beef steaks. J. Food Sci. 2012, 77, M108-M114. [CrossRef] [PubMed]

26. Luchansky, J.B.; Porto-Fett, A.C.S.; Shoyer, B.A.; Phillips, J.; Chen, V.; Kause, J.; Eblen, D.R.; Cook, V.L.; Mohr, T.B.; Esteban, E.; et al. Fate of Shiga toxin-producing O157:H7 and non-O157:H7 Escherichia coli cells within refrigerated, frozen, or frozen then thawed ground beef patties cooked on a commercial open-flame gas and a clam-shell electric grill. J. Food Prot. 2013, 76, 1500-1512. [CrossRef] [PubMed]

27. Luchansky, J.B.; Porto-Fett, A.C.S.; Shoyer, B.A.; Thippareddi, H.; Amaya, J.R.; Lemler, M. Thermal inactivation of Escherichia coli O157:H7 and non-O157 Shiga toxin-producing E. coli cells in mechanically tenderized veal. J. Food Prot. 2014, 77, 1201-1206. [CrossRef] [PubMed]

28. Ansay, S.E.; Darling, K.A.; Kasper, C.W. Survival of Escherichia coli O157:H7 in ground-beef patties during storage at 2, $-2,15$ and then $12{ }^{\circ} \mathrm{C}$ and $-20^{\circ} \mathrm{C}$. J. Food Prot. 1999, 62, 1243-1247. [CrossRef] [PubMed]

29. Phang, H.S.; Bruhn, C.M. Burger preparation: What consumers say and do in the home. J. Food Prot. 2011, 74, 1708-1716. [CrossRef] [PubMed]

30. Bogard, A.K.; Fuller, C.C.; Radke, V.; Selman, C.A.; Smith, K.E. Ground beef handling and cooking practices in restaurants in eight states. J. Food Prot. 2013, 76, 2132-2140. [CrossRef]

31. Black, E.; Hirneisen, K.; Hoover, D.; Kniel, K. Fate of Escherichia coli O157:H7 in ground beef following high-pressure processing and freezing. J. Appl. Microbiol. 2010, 108, 1352-1360. [CrossRef]

32. United States Department of Agriculture, Food Safety and Inspection Service. Testing of Raw Ground Beef Component (RGBC) Samples for E. coli O157:H7 and Non-O157 Shiga Toxin-Producing E. coli (STEC): Year-to-Date Totals. 2018. Available online: https://www.fsis.usda.gov/wps/portal/fsis/topics/datacollection-and-reports/microbiology/ec/rgbc-o157h7-and-stec-results-ytd/rgbc-stec-results-bv (accessed on 24 January 2020).

33. Garriga, M.; Grebol, N.; Aymerich, M.T.; Monfort, J.M.; Hugas, M. Microbial inactivation after high-pressure processing at $600 \mathrm{MPa}$ in commercial meat products over its shelf life. Innov. Food Sci. Emerg. Technol. 2005, 5, 451-457. [CrossRef]

34. Gola, S.; Mutti, P.; Manganelli, E.; Sauarcina, N.; Rovere, P. Behaviour of E. coli O157:H7 strains in model system and in raw meat by HPP: Microbial and technological aspects. High Press. Res. 2000, 19, 481-488. [CrossRef]

35. Ferrante, M. High-Pressure Processing-Keeping Foods Fresh, Healthy, and Safer. 2019. Available online: https://www.foodsafetymagazine.com/enewsletter/high-pressure-processing-keeping-foods-freshhealthy-and-safer/ (accessed on 17 December 2019).

36. Duffy, M. High-Pressure Processing: Outsourcing vs. in House. 2019. Available online: https: //www.provisioneronline.com/articles/107538-high-pressure-processing-outsourcing-vs-in-house (accessed on 17 December 2019).

(C) 2020 by the authors. Licensee MDPI, Basel, Switzerland. This article is an open access article distributed under the terms and conditions of the Creative Commons Attribution (CC BY) license (http://creativecommons.org/licenses/by/4.0/). 